reported the total membership had grown to 308 members with 21 registered during the year.

Vice-president is Alan Moss, Woodlands Manager, S. M. Simpson Ltd., Kelowna. Another member re-elected to Council was John S. Stokes i/c Management, B.C. Forest Service, Victoria.

New Council members are: W. Gerald Burch, Assistant Chief Forester, B.C. Forest Products Ltd., Vancouver; E. E. (Mike) Gregg, Director, Western Plywood Co. Ltd., Vancouver; Lorne F. Swannell, Ass't Chief Forester, i/c Operations, Victoria; and Thomas G. Wright, Chief Forester, Canadian Forest Products Ltd., Vancouver.

F. M. Knapp, Faculty of Forestry, U.B.C., was re-appointed Registrar.

F. M. KNAPP, REGISTRAR

\title{
ENTOMOLOGISTS MeET
}

The ninth annual meeting of the Entomological Society of Canada and the ninety-sixth annual meeting of the Entomological Society of Ontario will be held jointly with the annual meeting of the Entomological Society of America at Detroit, Mich., November 30 - December 3, 1959.

\section{INTERNATIONAL Botanical CONGRESS}

The Ninth International Botanical Congress will be held in Montreal, August 19-29, 1959, at the University of Montreal, McGill University and Sir George Williams College.

The first session of the International Botanical Congress was held in Brussels in 1864. It has been held only once before on this continent, in the U.S. This will be the first time it has been held in Canada. About 6,000 delegates from 72 countries are expected to attend; it will be by far the largest scientific conference ever convened in Canada.

The program of the scientific sessions will be conducted in 16 sections and will deal with all aspects of botany in its broadest sense, including plant production, breeding, and protection and their implications for agriculture and forestry. Some 400 selected leading scientists representing all sections of the program have been invited to present papers, participate in symposia and give public lectures. About 2,000 contributed or voluntary papers will also be given.

An extensive series of field trips constitute an important part of the Congress. Seventeen pre-Congress field trips and 7 post-Congress field trips have been organized, covering the period July 20 to September 14 . These trips will take foreign scientists to all parts of Canada, from coast to coast and to the sub-Arctic. Probably about 2,000 delegates will participate.

These trips will present unrivalled opportunities for scientists of the world to see Canada, and also to visit universities, research institutions and industrial developments. 